\title{
Wpływ fazy drgań ultradźwiękowych na strukturę i twardość napoin stopu aluminium 2017A
}

\section{Effects of the ultrasonic vibrations phase on structure and hardness surface-welds of 2017A aluminum alloy}

\section{Streszczenie}

W artykule przedstawiono wyniki badań struktury i twardości napoin uzyskanych metodami MIG na falowodzie w kształcie walca ze stopu aluminium 2017A. Badania miały charakter porównawczy i polegały na zestawieniu wyników uzyskanych napoin ze wspomaganiem drganiami ultradźwiękowymi oraz bez stosowania drgań. Celem zaprezentowanych badań było określenie wpływu fazy drgań ultradźwiękowych na strukturę i twardość uzyskanych napoin. Budowa strukturalna i twardość napoin uzyskanych z zastosowaniem drgań wykazywały zależność od ich fazy.

\section{Wstęp}

Prowadzone do tej pory prace badawcze wykazują, że istnieje wyraźny wpływ drgań mechanicznych na strukturę i właściwości złączy spawanych i napoin $[1 \div 15]$. Niezależnie od rodzaju spawanego materiału rodzimego i metody spawania obserwuje się zmianę budowy strukturalnej zarówno w strefie przetapianej, jak i w strefie wpływu ciepła. W dostępnej literaturze przedmiotu opisane są różne sposoby wprowadzania drgań do strefy spawania. Mogą to być przykładowo wibracje łuku elektrycznego $[4,5]$, oddziaływanie termiczne spójnej wiązki lasera [9], czy bezpośrednie doprowadzanie drgań do materiału rodzimego przez odpowiednio zastosowane falowody [6]. W wielu publikacjach na ten temat niestety nie omawia się szczegółów

Dr inż. Arkadiusz Krajewski - Politechnika Warszawska.

\section{Abstract}

The structure and hardness of the surface-welds and fusion-welds made on a 2017A aluminum alloy waveguide using the MIG method with and without the participation of ultrasonic vibrations were examined. Cross-sections of the fusions and surface-welds thus obtained were observed in a microscope and the hardness distributions were determined. The aim of the study was to analyze the effects of the ultrasonic vibrations applied to the melted metal pool by a vibrating substrate which in our experiments was a waveguide. The interactions of the ultrasonic vibrations with the molten metal during its solidification and also with the heat-affected zone were examined at various phases of the vibration wave. The ultrasonic vibrations affected the structure of weld. These changes are strongly depended of vibration wave phase.

technicznych dotyczących metod wprowadzania drgań. Z punktu widzenia kontroli zjawisk i wiarygodnego ilościowego opisu ich wpływu na uzyskiwane struktury, problem ten, jak i określenie wpływu fazy, amplitudy czy częstotliwości drgań na uzyskiwane struktury, wydają się kluczowe. W pracy [7] poruszono m.in. problem poprawy spawalności stopów aluminium. Autorzy uzyskali zmniejszenie wielkości ziaren, wzrost twardości w spoinie oraz ich spadek w strefie wpływu ciepła na skutek wprowadzania drgań, lecz sposób ich wprowadzania w strefę spawania niestety nie jest wyjaśniony i budzi wątpliwości co do możliwości kontroli amplitudy i dostarczanej energii. W pracy [8] omówiono spawanie metodą GTA stopu aluminium 7075 o wysokiej wytrzymałości poddawanego drganiom mechanicznym o częstotliwości od 105 do $2050 \mathrm{~Hz}$. Zaobserwowano zmniejszenie podatności na gorące pękanie stopiwa przy zastosowaniu drgań 1025 i $2050 \mathrm{~Hz}$. Drgania o częstotliwości $105 \mathrm{~Hz}$ spowodowały zaś wzrost podatności na pęknięcia gorące. 
Dzięki zastosowaniu drgań od 1025 do $2050 \mathrm{~Hz}$ podczas spawania stopu aluminium 7075 uzyskano strukturę o mniejszych ziarnach niż w przypadku użycia niższej częstotliwości drgań, a tym bardziej w porównaniu do gruboziarnistej struktury złączy spawanych bez drgań. Zastosowanie drgań mechanicznych w procesach spawalniczych prowadzące do poprawienia struktury i właściwości złączy zaprezentowano

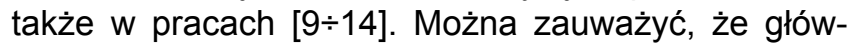
nym problemem podczas stosowania drgań mechanicznych w procesach spawalniczych jest techniczna trudność związana z bezpośrednią bliskością źródła ciepła oraz pola wysokich temperatur w materiale spawanym. Generalnie można stwierdzić, że odpowiednio wykorzystane drgania mechaniczne mogą korzystnie wpływać na strukturę i właściwości mechaniczne poszczególnych stref złączy spawanych. W opracowaniu [15] omówiono zastosowanie drgań ultradźwiękowych do wspomagania spawania laserowego, co pozwoliło uzyskać bardziej równomierny kształt lica, zwiększyć głębokość wtopienia oraz zmniejszyć prawdopodobieństwo powstawania pęknięć i porowatości przez zmniejszenie turbulentnego przepływu w jeziorku. Osiągnięcie pożądanych zmian struktury i właściwości złączy czy napoin z zastosowaniem drgań wymaga pełnej kontroli ich przebiegu, kierunku wprowadzania, jak i sterowania cyklem cieplnym. Tylko w nielicznych publikacjach można znaleźć zasygnalizowany wpływ parametrów drgań na budowę i właściwości struktur

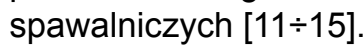

Na podstawie wcześniej przeprowadzonych badań

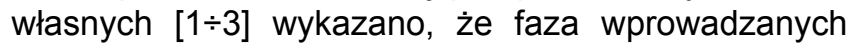
drgań do spawanego obiektu może determinować uzyskanie pożądanego lub szkodliwego efektu zmian w określonej strefie złącza. W niniejszej publikacji podjęto próbę wstępnej analizy termomechanicznej oddziaływania drgań ultradźwiękowych znajdujących się w określonej fazie. Znane są również z literatury [17, 18] zastosowania oddziaływania oscylacji ciśnienia plazmy, które umożliwia jednorodne rozproszenie ceramicznej fazy umacniającej w kąpieli metalicznej jeziorka spawalniczego podczas wytwarzania napoin kompozytowych. Ten sposób wprowadzania oscylacji jest niezależny od fazy drgań (nie wymaga stosowania falowodu) i należy się spodziewać, że może korzystnie wpływać na strukturę niezależnie od rozmiaru obrabianego obiektu.

\section{Odkształcenia i naprężenia wywołane drganiami ultradźwiękowymi}

Aby wybrać charakterystyczne i reprezentatywne zarazem miejsca przeprowadzenia badań strukturalnych i pomiarów twardości, wykonano także teoretyczną analizę przebiegu drgań (odkształceń/przemieszczeń) oraz naprężeń $w$ falowodzie poddawanym drganiom ultradźwiękowym o mocy $2,5 \mathrm{~kW}$, częstotliwości
$20 \mathrm{kHz}$ i amplitudzie $10 \mu \mathrm{m}$. Do opisu zjawisk związanych z wprowadzaniem drgań przyjęto następujące dane materiałowe: amplituda drgań podłużnych $A=10^{-5} \mathrm{~m}$, długość fali $\lambda=0,254 \mathrm{~m}$ równa długości falowodu, częstotliwość drgań $\mathrm{f}=20 \mathrm{kHz}$, gęstość stopu aluminium 2017A $\rho=2800 \mathrm{~kg} / \mathrm{m}^{3}$, prędkość fali $c=5080 \mathrm{~m} / \mathrm{s}$, współczynnik Poissona $v=0,33$, moduł Younga $\mathrm{E}=72,5 \mathrm{GPa}$. Do wyznaczenia przebiegów odkształceń (przemieszczeń) w zależności od współrzędnej długości falowodu $z=(0-\lambda)$ zastosowano klasyczne ujęcie matematyczne ruchu drgającego bez uwzględnienia tzw. zjawisk nieliniowych związanych z ograniczonymi wymiarami drgającego ośrodka czy tłumieniem.

Przemieszczenia podłużne $\varepsilon_{\mathrm{L}}$ i poprzeczne $\varepsilon_{\mathrm{T}}$ na skutek przebiegu fali stojącej drgań, jaka tworzy się $w$ falowodzie o długości $\lambda$, opisują zależności:

$$
\begin{gathered}
\varepsilon_{L}=A\left[\cos \left(2 \pi f \frac{\lambda}{c}+\varphi\right)+\cos \left(2 \pi f \frac{\lambda}{c}-\varphi\right)\right] \\
\varepsilon_{T}=-A v\left[\cos \left(2 \pi f \frac{\lambda}{c}+\varphi\right)+\cos \left(2 \pi f \frac{\lambda}{c}-\varphi\right)\right]
\end{gathered}
$$

gdzie: $\varphi$ jest kątem przesunięcia fazowego $(0,2 \pi)$.

W celu wyznaczenia naprężeń od ciśnienia akustycznego $P$, podłużnych $\sigma$, poprzecznych $\tau$ i zredukowanych wg hipotezy Hubera $\sigma_{z}$ wykorzystano formuły:

$$
\begin{gathered}
P=2 \pi \rho f c A, \sigma=P\left[\cos \left(2 \pi f \frac{\lambda}{c}+\varphi\right)+\cos \left(2 \pi f \frac{\lambda}{c}-\varphi\right)\right] \\
\tau=-v P\left[\cos \left(2 \pi f \frac{\lambda}{c}+\varphi\right)+\cos \left(2 \pi f \frac{\lambda}{c}-\varphi\right)\right] \quad \sigma_{Z}=\sqrt{\frac{\sigma^{2}}{2}+3 \tau^{2}}
\end{gathered}
$$

Na rysunkach 1 i 2 przedstawiono wyniki analizy drgań mechanicznych, generujących $w$ falowodzie określone przemieszczenia (odkształcenia) i naprężenia.

Jak można zauważyć na podstawie powyższych wyników, występuje symetria w następujących obszarach: $1 / 4 \lambda$ i $3 / 4 \lambda$ oraz $\lambda$ równe $0,1 / 2 \lambda i \lambda$. Aby badania były reprezentatywne dla charakterystycznych miejsc falowodu o długości $\lambda=0,254 \mathrm{~m}$, wystarczy zatem wykonać badania struktury i twardości $w$ dwóch tylko obszarach w odległości $z=1 / 2 \lambda=0,127 \mathrm{~m}$ i $z=3 / 4 \lambda=0,1905 \mathrm{~m}$ od zamocowania falowodu do układu drgającego.

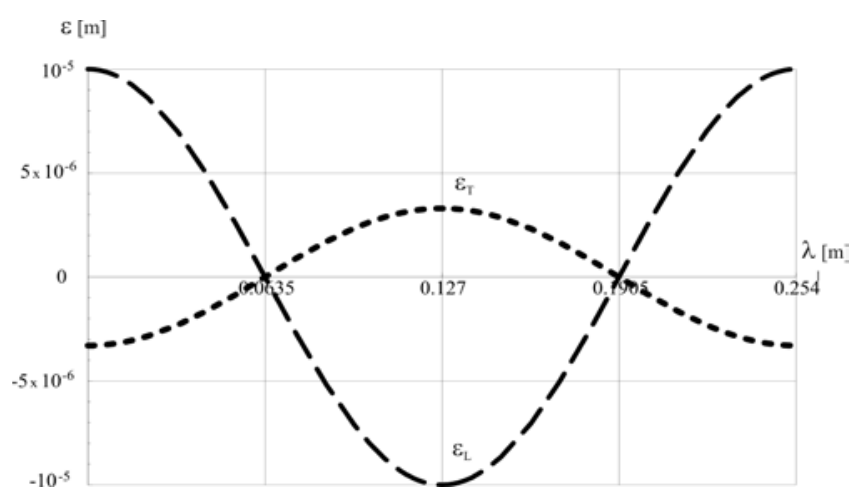

Rys. 1. Przemieszczenie podłużne $\varepsilon_{\mathrm{L}}$ i poprzeczne $\varepsilon_{\mathrm{T}} \mathrm{w}$ falowodzie Fig. 1. Longitudinal displacement $\varepsilon_{\llcorner}$and transversal displacement $\varepsilon_{\mathrm{T}}$ in a waveguide 


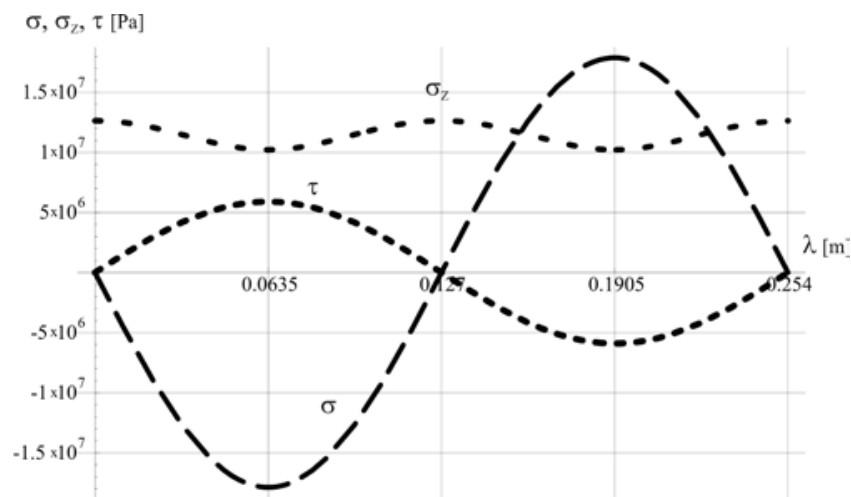

Rys. 2. Rozkład naprężeń osiowych s, poprzecznych $\tau$ i zredukowanych $\sigma_{z}$

Fig. 2. Distribution of axial stresses $\sigma$, transverse stresses $\tau$, and reduced stresses $\sigma_{z}$ in a waveguide

\section{Prace badawcze}

Przeprowadzone zostało napawanie metodą MIG z falowodem ze stopu aluminium 2017 (PA6), który miał formę walca o średnicy $45 \mathrm{~mm}$ i długości $254 \mathrm{~mm}$. Jego długość była równa długości fali ultradźwiękowej o częstotliwości ok. $20 \mathrm{kHz}$ w tym stopie. Uzyskano $w$ ten sposób falowód o długości pojedynczej fali drgań $1 \lambda$. Badania miały charakter porównawczy, a więc porównywano struktury i twardość uzyskanych napoin z udziałem drgań oraz bez nich.

W celu przeprowadzenia eksperymentu skonfigurowano stanowisko badawcze składające się z falowodu sprzężonego z przetwornikiem ceramicznym połączonym z generatorem ultradźwiękowym o mocy $2,5 \mathrm{~kW}$ za pomocą koncentratora o wzmocnieniu $1 / 1$, źródła firmy Fronius ALU Edition do spawania metodą MIG, a także z zestawu do zmechanizowanego spawania prostoliniowego firmy Fronius (rys. 3). Zestaw do zmechanizowanego spawania został sprzężony

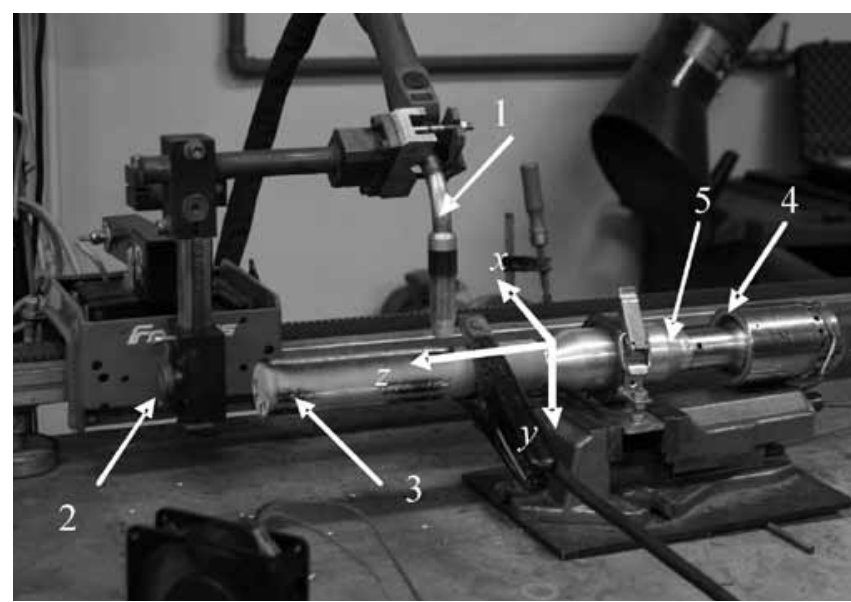

Rys. 3. Stanowisko do prób eksperymentalnych z układem drgajacym: 1 - głowica spawalnicza, 2 - pozycjoner, 3 - falowód, 4 - przetwornik ultradźwiękowy, 5 - koncentrator o wzmocnieniu 1/1

Fig. 3. Experimental set-up with vibrating system: 1 - welding torch, 2 - linear manipulator, 3 - waveguide, 4 - ultrasonic transducer, 5 - concentrator

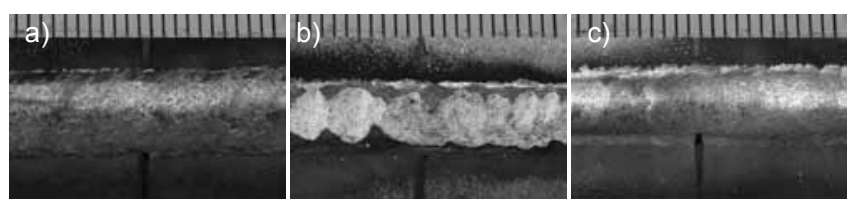

Rys. 4. Widok napoiny: a) bez drgań, b) $z$ drganiami $z=0,127 \mathrm{~m}$, c) $z$ drganiami $z=0,1905 \mathrm{~m}$

Fig. 4. MIG produced weld view: a) without vibrations, b) assisted with ultrasonic vibrations in the $0.127 \mathrm{~m}(1 / 2 \lambda)$ region, $c)$ with vibrations in the $0.1905 \mathrm{~m}$ region $(3 / 4 \lambda)$

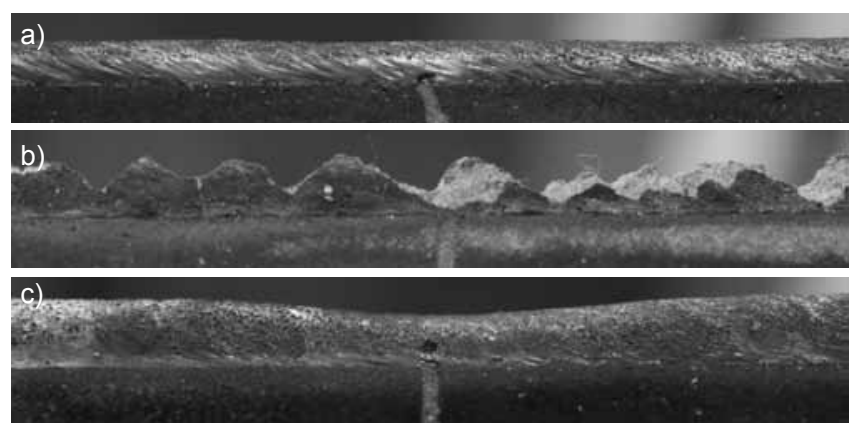

Rys. 5. Profil napoiny: a) bez drgań, b) $z$ drganiami $z=0,127 \mathrm{~m}$, c) $z$ drganiami $z=0,1905 \mathrm{~m}$

Fig. 5. Profile of the weld obtained by the MIG method: a) without the vibrations, b) with ultrasonic vibrations within the region $\mathrm{z}=0.127 \mathrm{~m}(1 / 2 \lambda), \mathrm{c})$ with ultrasonic vibrations in the region $z=0.1905 m(3 / 4 \lambda)$

z urządzeniami spawalniczymi w taki sposób, aby zajarzanie łuku oraz moment rozpoczęcia przejazdu głowicy były zsynchronizowane. Uchwyt spawalniczy w obu przypadkach był osadzony na ramieniu przymocowanym do zestawu mechanizacyjnego i ustawiony jak do spawania w pozycji podolnej, a oś uchwytu spawalniczego była ustawiona w pionie. Do napawania metodą MIG został użyty drut AIMg5 o średnicy $1,2 \mathrm{~mm}$. Proces został także całkowicie zautomatyzowany przez zsynchronizowanie zmechanizowanego przesuwu uchwytu spawalniczego wzdłuż wykonywanego napawania.

Wydatek argonu wynosił $17 \mathrm{l} / \mathrm{min}$, natężenie prądu $167 \mathrm{~A}$, napięcie łuku $19,4 \mathrm{~V}$, a prędkość spawania $0,0127 \mathrm{~m} / \mathrm{s}(0,73 \mathrm{~m} / \mathrm{min})$. Każda z kolejnych napoin była układana wzdłuż tworzącej walca, co $45^{\circ}$, aby uniknąć wzajemnego wpływu cyklów cieplnych poszczególnych napoin. Wysokość lica napoiny wynosiła 3 $\div 5 \mathrm{~mm}$ i zmieniała się w zależności od współrzędnej $z$. W odległości $z=0,1905 \mathrm{~m}$ od czoła falowodu nastąpiło zapadnięcie się lica o ok. $1 \mathrm{~mm}$ (rys. 5c). Natomiast dla współrzędnej $z=0,127 \mathrm{~m}$ nastąpiła dekompozycja lica spowodowana prawdopodobnie osiągającym maksimum odkształceniem (rys. 5b). Napoina ułożona bez udziału ultradźwięków cechowała się stałą wysokością nadlewu lica wynoszącą ok. $4 \mathrm{~mm}$. Na całej jej długości widoczne są pory w znacznie większej ilości niż w przypadku napoiny uzyskanej ze wspomaganiem drgań. Po napawaniu metodą MIG wykonano zgłady metalograficzne w wytypowanych powyżej przekrojach poprzecznych $(z=0,127 \mathrm{~m}$ i $z=0,1905 \mathrm{~m})$, które poddano później obserwacjom mikroskopowym i pomiarom mikrotwardości. Makrowidoki i profile uzyskanych napoin zamieszczono na rysunkach $4 \div 7$. 

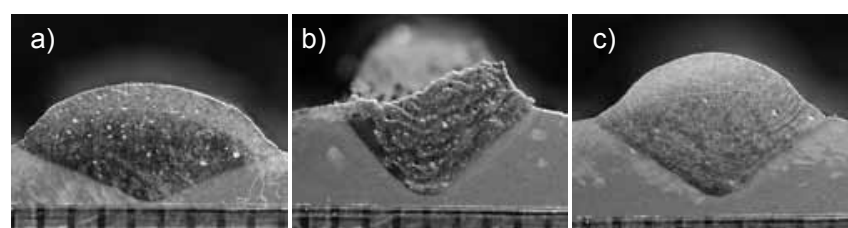

Rys. 6. Przekrój poprzeczny napoin: a) bez drgań, b) z drganiam $z=0,127 \mathrm{~m}, \mathrm{c}) \mathrm{z}$ drganiami $\mathrm{z}=0,1905 \mathrm{~m}$

Fig. 6. Cross-section of the MIG welds: a) without ultrasounds,

b) with the participation of ultrasounds at $z=0.127 \mathrm{~m}(1 / 2 \lambda)$,

c) with the participation of ultrasounds at $z=0,1905 \mathrm{~m}(3 / 4 \lambda)$

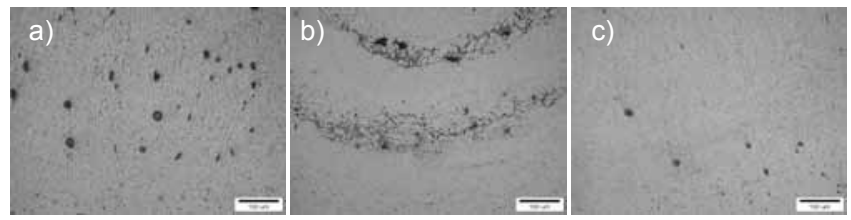

Rys. 7. Mikrografie (pow. 200x) napoin układanych metodą MIG: a) bez drgań, b) $z$ drganiami $z=0,127 \mathrm{~m}(1 / 2 \lambda), c) z$ drganiami $z=0,1905 \mathrm{~m}(3 / 4 \lambda)$

Fig. 7. Micrograph (magn. 200x) of the MIG welds: a) without ultrasounds, b) with the participation of ultrasounds $z=0,127 \mathrm{~m}(1 / 2 \lambda)$, c) with the participation of ultrasounds $z=0,1905 \mathrm{~m}(3 / 4 \lambda)$

Jak widać na zdjęciach powstałych napoin, przebieg fali ultradźwiękowej miał istotny wpływ na wygląd lica,

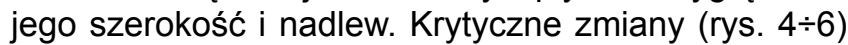
widoczne są w pobliżu węzłów $(z=0,1905 \mathrm{~m})$ oraz przy strzałce drgań $(z=0,127 \mathrm{~m})$.

Już po oględzinach zewnętrznych uzyskanych napoin można zauważyć, że w obszarach maksymalnej deformacji falowodu $(z=0, z=0,127 \mathrm{~m}$ oraz $\mathrm{z}=0,254 \mathrm{~m}$ ) występują „osmalenia” świadczące o zaburzeniach w ochronie gazowej i piłokształtna dekompozycja lica. W przypadku zastosowania drgań uzyskano szerokość lica dla $z=0,127 \mathrm{~m}$ $-8,5 \mathrm{~mm}$, zaś dla $z=0,1905 \mathrm{~m}-7,5 \mathrm{~mm}$.

Można zatem przypuszczać, że drgania ultradźwiękowe powoduja zjawisko podobne do zasysania bocznego powietrza pomimo występowania nadmuchu argonu z dyszy gazowej palnika. Prawdopodobnie tworzy się wówczas „poduszka powietrzna” w wyniku ciśnienia akustycznego drgań. Jest to proces niepożądany i nasila się w miejscach strzałki drgań, gdzie dodatkowo występują naruszenia ciągłości lica na skutek dekompozycji mechanicznej. Aby temu zaradzić, należałoby proces spawania prowadzić $\mathrm{w}$ komorze $z$ argonem.

\section{Wyniki pomiarów twardości}

Pomiary twardości wykonano metodą Vickersa pod obciążeniem $100 \mathrm{~g}$. Na rysunku 8 zestawiono reprezentatywne rozkłady twardości na charakterystycznych przekrojach poprzecznych napoin układanych metodą MIG. Każdy z punktów na wykresie jest średnią z czterech pomiarów.

Pomiary twardości nie wykazały zasadniczych różnic pomiędzy napoinami uzyskanymi z udziałem drgań
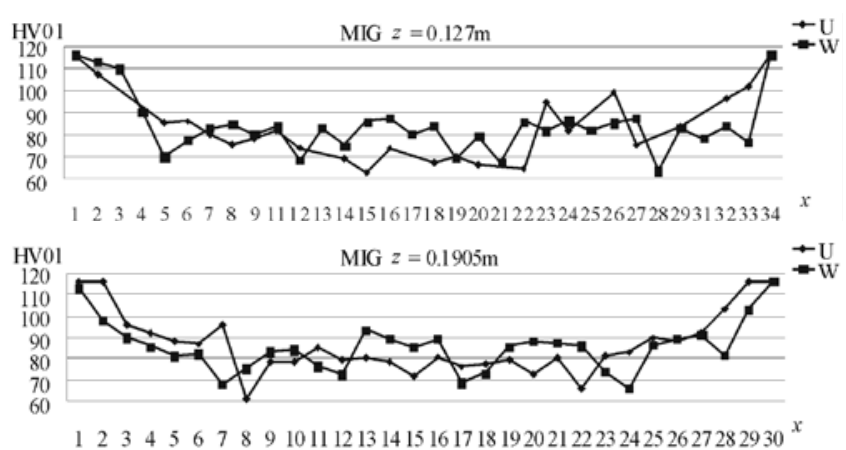

Rys. 8. Zestawienie rozkładów twardości na przekrojach poprzecznych uzyskanych napoin; $U-z$ drganiami, W - bez drgań, dz - działki na osi $x$ : a) $z=0,127 \mathrm{~m}, \mathrm{U}-180 \mu \mathrm{m} / \mathrm{dz}, \mathrm{W}-210 \mathrm{Mm} / \mathrm{dz}$; b) $z=0,1905 \mathrm{~m}, \mathrm{U}-250 \mu \mathrm{m} / \mathrm{dz}, \mathrm{W}-250 \mu \mathrm{m} / \mathrm{dz}$

Fig. 8. Hardness distributions on transverse cross-sections of the welds produced by $(U$ - with the assistance of ultrasounds, $B$ - without ultrasounds, div-divisions on the $x$ axis: a) $U-180 \mu \mathrm{m} /$ div, B - $210 \mathrm{Mm} / \mathrm{div}$; b) $U-250 \mu \mathrm{m} / \mathrm{div}, \mathrm{B}-250 \mu \mathrm{m} / \mathrm{div}$

i bez nich. Można jednak zauważyć, że zastosowanie drgań ultradźwiękowych powoduje pewne „spłaszczenie rozkładu", czyli bardziej równomierne rozłożenie wartości twardości niezależnie od współrzędnej pomiaru. Ponadto drgania powodują niewielkie obniżenie krzywej rozkładu i większy spadek twardości w SWC napoiny dla współrzędnej $z=0,1905 \mathrm{~m}$.

\section{Podsumowanie}

Aby właściwie zinterpretować budowę strukturalną charakterystycznych obszarów napoin uzyskanych metodą MIG (rys. 7), należy określić wpływ temperatury maksymalnej cyklu cieplnego w określonym miejscu napoiny i odnieść go do fazy drgań ultradźwiękowych [16]. W tym celu wykreślono rozkład temperatury w zakresie likwidus-solidus $\left(645 \div 510^{\circ} \mathrm{C}\right)$ w zależności od przyjętych parametrów spawania, właściwości

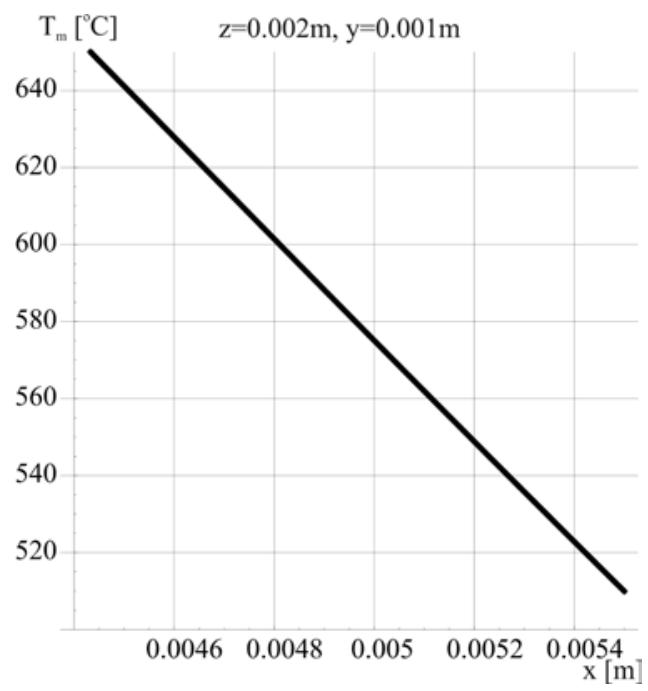

Rys. 9. Rozkład temperatury w falowodzie podczas spawania metodą MIG

Fig. 9. Distribution of the temperature in MIG welding 
termicznych zastosowanego stopu 2017 oraz współrzędnych kartezjańskich procesu. Na rysunku 9 przedstawiono wyniki takiej analizy dla średnich współrzędnej położenia y $=0,001 \mathrm{~m}$ związanej z głębokością w odległości $z=0,002 \mathrm{~m}$ od źródła ciepła. Wynika z niej, że odległość pomiędzy frontem krystalizacji determinowanym temperaturą krzepnięcia a temperaturą topnienia wynosi niewiele ponad 0,001 m.

Zaprezentowane wyniki tej analizy nie uwzględniają wymiany ciepła z otoczeniem ani radiacji, mogą zatem być traktowane jedynie jako przybliżenie górnej granicy możliwych wartości. Niemniej jednak można pokusić się o pewne podsumowanie, gdy porównamy strukturę z rysunku $7 \mathrm{~b}$ z otrzymanymi wynikami analizy. Otóż wyraźnie widać, że w przypadku napoiny uzyskanej metodą MIG ze wspomaganiem drganiami można ustalić odległość między kolejnymi frontami krystalizacji $0,0005 \mathrm{~m}$, a więc dwukrotnie mniej niż wynika to z wykresu na rysunku 9. Warto zauważyć także, że w przypadku swobodnego krzepnięcia napoiny uzyskanej bez udziału drgań (rys. 7a), jak i dla napoiny krzepnącej (rys. 7c) w węźle drgań ( $z=0,1905 \mathrm{~m}$ ) nie obserwuje się występowania budowy „pasmowej”. W wyniku zastosowania drgań ultradźwiękowych dużej mocy występujących w strzałce $(z=0,127 \mathrm{~m})$ energia kinetyczna cząstek ciekłego jeziorka jest maksymalna, co prawdopodobnie jest przyczyną rozbijania frontów krystalizacji. Obserwujemy zatem wyraźnie układające się pasmowo obszary.

\section{Wnioski}

Na podstawie przeprowadzonych badań można wyciągnąć następujące wnioski:

- Zastosowanie podłużnych drgań ultradźwiękowych o dużym natężeniu w procesie spawania przynosi korzystne efekty w budowie strukturalnej napoin jedynie w fazie będącej nieparzystą wielo-

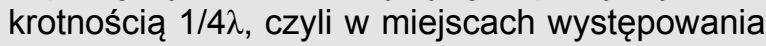
węzłów drgań. Ponadto występuje w tym przypadku niewielkie wklęśnięcie lica spowodowane prawdopodobnie ściskającymi naprężeniami wywołanymi w węzłach. Występują wtedy korzystne efekty w postaci rozdrobnienia ziarna i zmniejszenie porowatości.
- W strzałkach drgań dla całkowitych wielokrotności $1 / 2 \lambda$ obserwuje się powstawanie dyskwalifikującej dekompozycji lica i bardzo wyraźną strukturę pasmową spoin/napoin. Jest to prawdopodobnie wynikiem występowania naprężeń rozciągających (w przypadku stopu 2017A o wartości ok. $13 \mathrm{MPa}$ ), co na pograniczu temperatury krzepnięcia i topnienia powoduje przekroczenie spójności materiału lica. Zastosowanie drgań w „strzałkach” drgań powoduje ponadto utratę skutecznej osłony gazowej, przyczyniając się do nasilenia porowatości.

\section{Literatura}

[1] Krajewski A.: Wspomaganie procesów spawalniczych drganiami mechanicznymi, Zeszyt Naukowy nr 229, s. 33-51 (seria Mechanika), pt. Innowacje w technikach spajania, Oficyna Wydawnicza Politechniki Warszawskiej, 2009.

[2] Krajewski A.: Badanie wpływu pola ultradźwiękowego na budowę i właściwości struktur spawalniczych, Zeszyt Naukowy nr 230, s. 71-82 (seria Mechanika), pt. Spajanie materiałów we współczesnej technice, Oficyna Wydawnicza Politechniki Warszawskiej, 2010.

[3] Krajewski A.: Drgania mechaniczne w procesach spawalniczych, Przegląd Spawalnictwa nr 6, s. 37-42, 2011.

[4] Longbiao H., Minsheng W., Luming L., Hongwei H.: Ultrasonic generation by exciting electric arc: A tool for grain refinement in welding process, Applied Physics Letters, 89, 131504, 2006.

[5] Lei Y.C., Wang Z.W., Chen X.Z.: Effect of arc ultrasound on microstructures and mechanical properties of plasma arc welded joints of SiCp/Al MMCs, Transactions of Nonferrous Metals Society of China, 21, s. 272-277, 2011.

[6] Farrow M.: Laser/ultrasonic welding technique, United States Patent 4330699, 1982.

[7] Weng-Long D.: Effects of high-intensity ultrasonic-wave emission on the weldability of aluminum alloy 7076-T6, Materials Letters 57, s. 2447-2454, 2003.
[8] Dong H., Yang L., Dong C., Kou S.: Improving arc joining of Al to steel and Al to stainless steel, Materials Science and Engineering, A 534, s. 424-435, 2012.

[9] Balasubramanian K.: Studies on the effect of vibration on hot cracking and grain size in AA7075 aluminum alloy welding, International Journal of Engineering Science and Technology, Vol. 3, No. 1, Jan. 2011.

[10] Qingmei L., Yong Z., Yoling S., Feipeng Q., Qijie Z.: Influence of ultrasonic vibration on mechanical properties and microstructure of $1 \mathrm{Cr} 18 \mathrm{~N} 9 \mathrm{Ti}$ stainless steel, Materials and Design, 28, s. 1949-1952, 2007.

[11] Cui Y., Xu C. L., Han Q.: Effect of ultrasonic vibration on unmixed zone formation, Scripta Mater. 55, s. 975-978, 2006.

[12] Weng-Long D.: Effects of high-intensity ultrasonic-wave emission on the weldability of aluminum alloy 7076-T6, Materials Letters 57, s. 2447-2454, 2003.

[13] Kim. S., Watanabe T., Yoshida Y.: Ultrasonic vibration aided laser welding of $\mathrm{Al}$ alloys: improvement of laser weldingquality, Department of precision \& Production Engineering and Facility of Engineering, Chiba University, Japan, Journal of Laser Applications, 1995.

[14] Weite W.: Influence of vibration frequency on solidification of weldments, Scripta Mater. 42, s. 661-665, 2000. 
[15] Zhiwu X.J.Y., Gaohui W.X., Kong S.Y.: Interface structure of ultrasonic vibration aided interaction between $\mathrm{Zn}$-Al alloy and $\mathrm{Al}_{2} \mathrm{O}_{3} \mathrm{p} / 6061 \mathrm{Al}$ composite, Composites Science \& Technology, No 65, 2005.

[16] Chon L., Chin M.T.: ASM Hand Book vol. 6, Welding and Soldering, Heat Flow in Fusion Welding, 1993.
[17] Włosiński W., Chmielewski T.: Wpływ rodzaju umocnienia ceramicznego chromowych powłok ochronnych nakładanych plazmowo na ich zwilżalność szkłem, Kompozyty - Ogólnopolskie specjalistyczne czasopismo naukowo-techniczne, Wydawnictwo Politechniki Częstochowskiej, Rocznik 2, nr 5, 2002.

[18] Włosiński W., Chmielewski T.: Plasma-hardfaced chromium protective coatings - effect of ceramic reinforcement on their wettability by glass, Advances in Science and Technology 32 , s. $253-260,2003$

\section{Poniższe artykuły zostaną opublikowane 2/2013 Miesięcznika Naukowo-Technicznego Przegląd Spawalnictwa}

Sławomir Krajewski, Jerzy Nowacki

\section{Właściwości połączeń spawanych ze stali dwufazowych - DP}

W pracy przedstawiono wyniki analizy wartości równoważnika węgla $C_{e}$ stali dwufazowych DP ze stalami wielofazowymi CP i TRIP, konwencjonalnymi o wysokiej granicy plastyczności do obróbki plastycznej na zimno LAD+BD+YD i o podwyższonej granicy plastyczności w stanie ulepszonym cieplnie. Przedstawiono również wyniki badań metalograficznych i wybranych właściwości mechanicznych złączy spawanych metodą spawania GTAW stali dwufazowych: DP600Z140+M, DP800Z140+M i DP1000Z140+M.

\section{Lechosław Tuz, Andrzej Kolasa}

\section{Wpływ wybranych parametrów spawania łukowego na spawalność odlewniczych stopów magnezu}

W artykule przedstawiono wpływ wybranych parametrów spawania łukowego na jakość złączy spawanych odlewniczych stopów magnezu należących do grupy Mg-Al-Zn.

W badaniach zastosowano dwie metody spawania łukowego w osłonie gazów obojętnych: elektrodą topliwą (MIG) i nietopliwą (TIG). Przedstawiono wyniki obserwacji wizualnych wykonywania złączy doczołowych, orazich ocenę makroskopową. W pracy skoncentrowano się na określeniu wpływu takich parametrów jak: rodzaj i natężenie prądu, napięcie łuku i prędkość spawania na wartość energii liniowej wykonywanych złączy oraz ich jakość (brak pęknięć gorących i porowatości).

Dariusz Fydrych, Jerzy Łabanowski

\section{Zastosowanie techniki ściegu odpuszczającego do spawania mokrego}

W artykule przedstawiono zastosowanie techniki ściegu odpuszczającego do poprawy właściwości złączy ze stali konstrukcyjnych wykonywanych w warunkach mokrego spawania pod wodą. Scharakteryzowano istotę spawania mokrego elektrodami otulonymi oraz ideę zmiany struktury i własności złączy spawanych poprzez nakładanie ściegów odpuszczających. Przedstawiono metodykę oraz wyniki badań metalograficznych i twardości próbek ze stali konstrukcyjnej o podwyższonej wytrzymałości z napoinami próbnymi wykonanymi pod wodą. Ustalono, że zastosowana technika może stanowić sposób zmniejszenia twardości napoin w warunkach praktycznych. Wyznaczono również optymalny zakres odległości między napoinami (podziałki).

Krzysztof Pańcikiewicz, Edmund Tasak

\section{Charakter pękania połączeń spawanych stali 7CrMoVTiB10-10 (T24)}

W artykule omówiono pękanie połączeń spawanych stali 7CrMoVTiB10-10 (T24), stosowanej na ściany szczelne w kotłach energetycznych, pracujących przy parametrach nadkrytycznych. Jednym z powodów pękania, ze względu na mikrostrukturę materiału spawanego, może być negatywne oddziaływanie wodoru, zarówno podczas spawania, jak i eksploatacji. Stosowanie obróbki cieplnej po spawaniu poprawia właściwości plastyczne złączy, ale może wywoływać również pękanie relaksacyjne. 